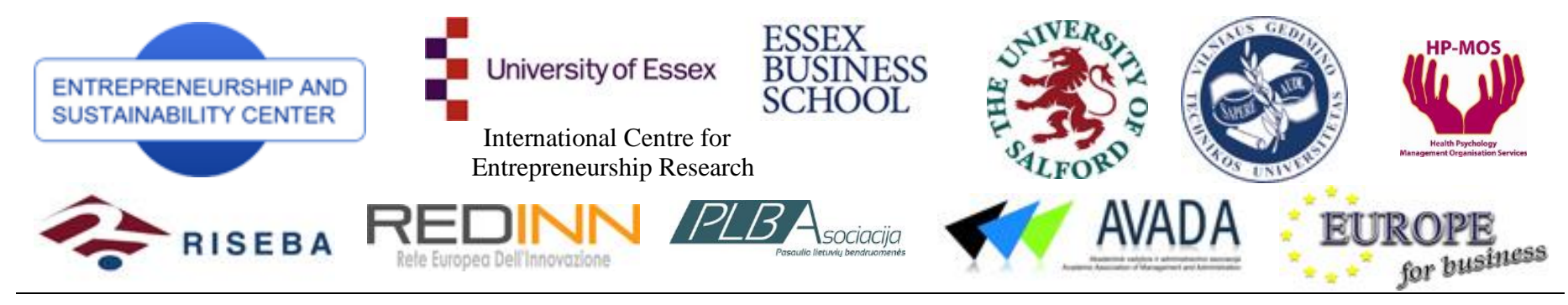

The International Journal

ENTREPRENEURSHIP AND SUSTAINABILITY ISSUES

ISSN 2345-0282 (online) http://jssidoi.org/jesi/aims-and-scope-of-research/

2015 Volume 2 Number 3 (March)

\title{
HOW TO KEEP OPEN-SOURCE BASED INNOVATION APPROACHES SUSTAINABLE: A VIEW FROM THE INTELLECTUAL PROPERTY PERSPECTIVE
}

\author{
Thomas Hoffmann', Gunnar Prause ${ }^{2}$ \\ ${ }^{1}$ Tartu University, Näituse 13a, 50409 Tartu, Estonia \\ ${ }^{2}$ Tallinn University of Technology \\ Akadeemia tee 3, 12618 Tallinn, Estonia \\ E-mails: 'thomas.hoffmann@ut.ee; '2gunnar.prause@ttu.ee
}

Received 15 December 2014; accepted 10 February 2015

\begin{abstract}
Open Source-based innovation has an exponentially increasing significance for companies seeking to improve their product portfolio without maintaining a costly research department. The abundant product-related data provided by users in virtual communities in form of comments, feedbacks, and recommendations is already today an essential source of innovation for the goods- producing, but also the tertiary sector. While these data are basically freely accessible on the web, the questions remains in how far this approach is sustainable, i.e. secure and safe also in legal terms. In fact, there are various intellectual property issues protecting the user's contribution (see e.g. copyrights, patents, utility- and design models) which are often not taken into account by companies making use of the respective data, causing an eventual infringement of protected rights and therefore the sustainability of the company's innovation policy.
\end{abstract}

Keywords: Open Source-based innovation, sustainability, user-driven design processes, virtual communities, intellectual property rights

Reference to this paper should be made as follows: Hoffmann, T.; Prause, G. 2015. How to keep open-source based innovation approaches sustainable: a view from the intellectual property perspective, Entrepreneurship and sustainability issues 2(3): 133-141.

DOI: $\underline{\text { http://dx.doi.org/10.9770/jesi.2014.2.3(2) }}$

JEL Classifications: O34

\section{Introduction}

Innovation is the key driving factor for economic growth and social wealth; but nowadays, innovation is increasingly complex, fast, inter-active and relies on connecting external and internal knowledge bases (Pavitt 1984; Chesbrough 2003; Asheim and Gertler 2005; Malerba 2005; Figurska 2014). So firms acquire knowledge from a variety of sources and actors at various spatial scales (Smith 2000; Tödtling et al. 2006; Figurska 2014), combining it with internal knowledge and competences through different transfer channels (Gilsing et al. 2011, Tvaronavičienè 2014). In open and user-driven innovation approaches the customer takes over the role of an active co-designer in the creation of value. The data provided by users in virtual communities in form of comments, feedbacks, recommendations on the web are touching various intellectual property issues, and their unauthorized use eventually infringes protected rights. 
Cooper and Kaplan (1999) considered life-cycle costs of products according to their phases and differentiated between committed costs and costs incidence. In a more recent paper Specht et al. (2002) were able to give a more detailed view of committed and realized success dimensions of products during their life cycle. The considered success dimension were costs, quality, time lines, flexibility and differentiation and the phases of life-cycle consisted of product development, procurement, production, sales and distribution, usage and MRO, and finally return. Both scholars see the highest part of the committed costs in the product and process planning and design phase with up to $80 \%$. Improvements and innovation in product and process development phase significantly contribute to company success and profit.

Traditionally, innovation management and product development were driven by internal company forces, but in recent times more and more companies are using open innovation approaches to improve their products. In a survey comprising 2840 large companies in the USA and Europe Chesbrough and Brunswicker (2013) conducted a large sample survey about open innovation in large firms with an annual sale exceeding US\$250 million. The survey revealed that $78 \%$ of the large firms are practicing open innovation - and this more intensively than three years ago. Customer co-creation, informal networking, and university grants were the three leading practices in 2011 whereas crowdsourcing and open innovation intermediary services enjoyed the lowest rates of importance. The typical large firm in the survey spent in 2011 US\$ 2 million on open innovation which is equivalent to 20 company employees doing the same work.

There always has been also a focus on consumers as valuable knowledge sources since future buyers could best judge what would lead to commercial success and what not (Jaworski and Kohli 1993). Hence, more and more firms engaged in customer involvement for new product ideas which would easily be implemented and highly appreciated by customers (Kristensson et al. 2004). Originally, user innovators were defined as those individuals who develop new products and services based on their own perceived needs without the assistance and involvement of producers (von Hippel, 1988). In his recent research, von Hippel introduces some measures to quantify the importance of users in the innovation process and suggests that billions of dollars are spent annually by users to improve products and make them better suited to their needs (von Hippel et al. 2011; 2012). With respect to scale, von Hippel's surveys found that millions of users collectively spend billions of dollars every year on developing and modifying consumer products.

Since valuable consumer-related knowledge is widely dispersed, recent solutions for the integration of large numbers of consumers into the innovation process are mainly based on information technology (Web 2.0). These online communities contribute to company's profit, and related topics like the protection of intellectual property rights (IPRs) and the participation of user innovators in additionally generated company profits have recently been a major issue in the field of employee's inventions and non-affiliated private innovation contributions of any kind. Most the abundant product-related data provided by users in virtual communities, appearing in form of comments, feedbacks or recommendations, are basically freely accessible on the web, although the "authors" of these innovations generally have various protected intellectual property rights. Unfortunately these IPR issues are often not taken into account by companies making use of the respective data, causing an eventual infringement of IP rights.

\section{Literature review}

Since innovation becomes more and more complex, fast, interactive, companies acquire knowledge from a variety of different sources and actors, and combining these with internal, external and localized knowledge and expertise is crucial for competitiveness, as innovation processes in the interplay between local and complementary global knowledge (Porter 2000; Chesbrough 2003; Gertler and Levitte 2005; Boschma and Ter Wal 2007). Despite the multitude of insights into technology transfer, remarkably little is known about how transfer processes are shaped by the underlying industry and its technical regimes (Breschi et al. 2000; Marsili 2001; Gilsing et al. 2011). Young and Tilley (2006: 402) as well as Cohen and Winn (2007: 35) are stressing the efficiency and effectiveness in an inter-generational economic consideration for the future to characterize sustainable entrepreneurship, i.e. sustainable entrepreneurship is in line with entrepreneurs heading for profit and improving environmental sustainability and social conditions so that the long-term economic and business consequences of new venture 
opportunities become the central issue. Unfortunately the current discussions and concepts about sustainable entrepreneurship are oriented on larger companies than on the SME sector so that Gerlach (2003) proposes three strategies to implement sustainable entrepreneurship concepts based on sufficiency, efficiency and consistency. User-driven innovation in form of online communities can be considered, by following Bartl (2008), as an open innovation approach, which underscores the way of going beyond the corporate boundaries, i.e. an active strategic deployment of environmental clout or external factors of influence to increase its own innovation potential. Crucial determinants of such concepts are the shift from an industrial society to a network-based knowledge and communication society.

Additionally, open innovation encompasses such manifestations as to be open for the knowledge of the other, generation of the knowledge as a joint action as well as the share of the knowledge with the other. Besides, an important role for the phenomenon of open innovations plays the customer. In the course of innovation management, a new role model of the customer was generated when developing new products or offering new services, opening a new field of management (Gibbert et al. 2002). In this sense, open innovation emerges also when the customer is involved into the process of generation. Therefore, it is vital to adapt to customer's needs and requirements as well as wishes in the customer goods markets. Furthermore, it is essential to integrate the customer into the entrepreneurship innovation-related activities as a new external knowledge and ideas source (Bartl 2008: 3-4). Zhao (2005) confirmed that entrepreneurship and innovation are positively related to each other and interact to help an organization to flourish, i.e. entrepreneurship and innovation are complementary, and a combination of the two is vital to organizational success and sustainability. He also pointed out that the organizational culture and the management style are crucial factors affecting the development of entrepreneurial and innovation behavior in organizations. Comparing user-driven innovation with other innovation models, the private-collective innovation model (Gächter et al. 2010) has been analyzed and juxtaposed against the private investment model. Taking a legal perspective on user-driven innovation, the research for this paper focused on employee's invention law, protecting the non-profiting inventor in a very similar way (Bales 2013), and took the regulation of the issue as developed by German law (Schwab 2014) as model regulation for user driven innovation.

User communities in innovation have been mainly investigated with a focus on new product development. Prandelli et al. (2008) analyzed and developed a classification system for new product development (NPD) of user communities, which also considered the start of the life-cycle supply chain, i.e. the development of new products. In order to cover the full life-cycle oriented supply chain by user driven innovations it is necessary to look for different portals of user communities. After product development the next stage in product life-cycle is related to production or operation. The dominating questions in recent manufacturing are related to how to tackle mass customization and how to construct and integrate performant supply chains (Simchi-Levi et al. 2010; Heizer and Render 2013). In both cases the postponement concept describes the crucial question, i.e. where exists the freezing or postponement point between the push and the pull part in the supply chain (Boone et al. 2007). The benefits of the involvement of user innovation communities for companies can be estimated from the life-cycle supply chain model of Cooper and Kaplan (1999) in a more detailed way from Specht et al. (2002). Both authors estimate the committed costs for product and process development and design phase up to 80\%. But Specht et al. (2002) not only restrict their view on costing and product development; they consider all success dimensions in different lifecycle phases for the product like quality and product differentiation. These figures have to be balanced with the tentative IPR costs for user innovation involvement.

\section{Method}

The research process described in the paper has pursued a manifold research path, whereby diverse research methods have been combined with the respective research approach and research tool. Five techniques were employed in exploring the objectives of the present paper:

- Research types: analytical, qualitative, historical, empirical, practice-based

- Research approach: qualitative

- Research methods: descriptive and qualitative - case studies, semi-structured interviews, expert assessments and observations

- Research scope: different research activities in 2013 and 2014. 
The reasoning behind the selection of the following techniques in the research process is elaborated in the following.

Regarding the research types, the paper has chosen analytical, qualitative, empirical and practice-based way, since during the research process the facts and empirical evidence gathered were appropriately analyzed and subject to a critical assessment. The core of the research process is the qualitative research approach. Important insight views were given in qualitative expert interviews and the analysis of case studies (Prause and Thurner 2014).

\section{IPR protection schemes in open and user-driven innovation}

From an IPR point of view, user-driven innovation can be differentiated on base of the nature of the innovation target:

Either innovators contribute privately and voluntarily to a public good, i.e. to a good or product which is freely available on the market. This model, known as "private-collective innovation" (von Hippel and Krogh 2003), is applied for instance often in the IT branch to develop and maintain open source software; well-known examples are Linux or Firefox. The model contrasts with the (traditional) private-investment model, where innovation is generated exclusively by the company itself, which - in return - has to amortize its prior investments via granting licenses to users. It therefore is bound to protect the achieved innovations, e.g. via licensable IP rights. In privatecollective innovation, the privately generated innovation is not regarded as an "investment", but rather as a voluntary contribution to a common good, making the innovator waive any copyright and further IP rights as soon as the innovation has been shared with others (Lerner and Tirole 2002a; b).

But not only the individual innovator refrains from his rights, also firms waive their IPRs extensively, realizing that making their technical state-of-the-art freely available to the public generates a much higher return in terms of innovation than the private-investment model (Henkel et al. 2013). Although innovators "invest" considerably time, energy, knowledge and other resources without any expectancy of financial gratification, the privatecollective innovation model proved to be very successful in practice (Gächter et al. 2010) and gave grounds to extensive research recently, especially concerning the contributor's intrinsic motivation for their free commitment (see e.g. Alexy and Reitzig 2013).

From a legal point of view, there is little demand for a balance of interest to be achieved by instruments of intellectual property law, as the free use of otherwise protected rights form the essence of the "Open Source Scene's Spirit": All parties involved in open source innovation are aware that they - expressly or impliedly waive their respective IP rights, driven by the awareness that they jointly improve a "common good". But not all open or user-induced innovations contribute to public goods. The innovation beneficiary more and more often happens to be a private and profit-oriented company, making the private user providing innovation not any more to a public good, but to private assets of that company - e.g. sport sailors disclosing improvements they made to sailing equipment on the sailing equipment's company's homepage. The value generated by this innovation is not any more freely available on the market, but has to be purchased by each sailor (or other kind of customer) individually.

Form a legal point of view, the exchange of interest in this situation not as balanced as in the Open Source Scene, and correction measures imposed by law may be required. As these contributions are of immaterial character, these correction measures - in other words forms of legal protection - must be sought among the existing intellectual property protection schemes. A central instrument aiming at the protection of technical improvement is the patent, either in form of national or international/European patents. A patent is basically the right to exclude competitors from the usage of an invention and is effected only upon registration, which will be granted upon application by national or international/European patent offices if evidence has been provided for following criteria: There must be a patentable subject matter (no patents will generally be granted e.g. on alterations of the human body), the invention must be novel - i.e. non-existent so far world-wide -, the invention must be non-obvious (in U.S. law) or must involve an inventive step (in European law), and the invention must be useful for a concrete purpose.

A granted patent is a strong and effective right, granting the patent-holder a broad range of rights ranging from monetary compensation for past infringements to injunctions against future infringements - although its role in 
innovation has recently been a controversial issue, as it is sometimes claimed that innovation virtually cannot be harmed more than by the exclusion of others from knowledge (Hall 2014: 26).

In fact, every user-generated innovation communicated via virtual communities could generally be patented by the user, if the innovation fulfils the above-mentioned criteria. Returning to the sport sailor's example, the sailor's suggestion to improve e.g. the rope winch for a sailing boat is generally a patentable subject matter, which is eventually - novel, non-obvious/involving an inventive step and it is quite probably useful as well. In other words, the sport sailor could hand in the same description of this rope winch improvement which he put online at the virtual community (or sailing equipment company's homepage) at his regional - or, if he is seeking for international exclusion rights, at an international - patent office, as far as he extended/supplemented it respectively (the description must meet the formal criteria of the patent office) and is ready to pay the respective fees.

Still, the mere ability to patent an invention does not grant yet a comprehensively protected right: The invention itself - even if communicated to the public - is not yet property-like protected and also does not deserve yet protection, as there is no form of intellectual property in mere ideas (Tönnies 2013). The inventor will have the exclusive right to use his invention (or to, practically just as important, grant a license to third parties for that patent) once the patent has been granted successfully. There is a certain debate about the protection of patent applicants between the time of submission of the application to the patent office and the final grant of the patent which may take years -, as in this case the applicant has already demonstrated to the public that he requests a comprehensive exclusion right in (hopefully) near future; so far, most legal systems nevertheless would grant a mere compensation to be paid by the infringer to the applicant instead of the full range of patent defense rights mentioned above (see e.g. for German law Pahlow 2008).

\section{Findings: Low IPR protection level}

Returning to the typical situation in which user communicate their inventions online, on first sight the protection of users by these classical IPR protection mechanisms seems far-fetched, as in case of the average user, even this basic step of an application has not been reached yet (and is also not endeavored by him). Before application, there is generally no active right on base of which the inventor may prevent the usage of his patent by others: The sport sailor may, e.g., not seek a court injunction against the sailing equipment company which produced an improved rope winch modelled after the sailor's descriptions on a virtual community or the company's website. Patent law in so far does not directly protect the user's invention from the "exploitation" of the invention by private companies.

If the rope winch did not involve an essential inventive step, but merely a minor improvement, many States provide protection for these improvements in forms of the protection as a utility model, which can be seen as a "small patent". The procedure to protection a technical improvement in form of a utility model is generally comparable to the patent procedure, but requires less costs, fees and conditions - while respectively the scope of protection will be considerably smaller as well. But also here, protection as a utility model will again be only effected after successful grant of the registration as a utility model, and as users generally will not have applied for this kind of protection either, their legal position remains generally defenseless in this context.

In conclusion, a user communicating an invention online does not have the right to prevent other persons to make use of his improvement. But the situation changes if the private company seeks protection of its legal position from the usage of that improvement against other third persons: The sailing equipment company may eventually intend to hand in itself a patent for that rope winch development by that sport sailor, based on the descriptions put on the internet by the sport sailor.

\section{Implications: A new approach for protecting innovating users}

When the sailing equipment company will hand in a respective application for a patent or a utility model at the competent office, the office will check - among other conditions - the novelty of the invention/improvement. If 
the company did not even disclose itself the origin of the invention, a thorough research by the office may reveal the sport sailor as inventor, who, in this case, also made his invention publically available - depriving it from its novelty. Although details are controversial in national patent law systems (they essentially differ whether they provide a grace period for filing an invention - e.g. U.S. law - or follow a "file first, publish later doctrine - e.g. Germany; Klett 2008: 4), the lack of novelty will considerably weaken the company's legal position: Depending on the respective legal regime (national or international law, depending on the function of the patent/utility model office), the sport sailor could file a notice of opposition within a special opposition period (e.g. nine months for a European patent, three months for a German patent; for background see Klett 2008: 12).

But also if no notice of opposition was filed/the office did not find the actual source of the invention and the patent was successfully granted to the company, the company remains endangered that the user will later hand in an action for nullification of the patent, as the conditions for its grant had not been met: If the patent holder was not entitled to hold the patent, the patent will be revoked - e.g. European patents acc. to art. 139 European Patent Convention (for European patents), national patents according to respective national patent acts (for e.g. German law acc. to act. 81 Patent act).

In other words: If a company endeavors a sustainable exploitation of a patent or a utility design - and the more useful the invention is, the more probable this endeavor will be -, it has in some way to cooperate with the author of the innovation. Otherwise, it will run the constant risk of a later revocation of the patent - or, although less likely, the application for a respective patent by the inventor itself, which then would exclude the company also from the further usage of the invention in its products. Although therefore a clear demand for the regulation of these forms of cooperation exists, the legal protection of user's interest in the context of user-driven innovation has not yet been settled. Still, there is a similar constellation of interests which already has been regulated in detail by law: Just as in user-driven innovation, an employee not holding any personal shares in the profit of a company generates innovation through suggesting improvements he or she invented through the daily use of products or application of production procedures, which lead to the improvement of these products and procedures and increase the profit of the producing company. These employee's inventions constitute e.g. in Germany about 80 $\%$ of all inventions (Schwab 2014) and have therefore ben subject to various acts and statutes.

In fact, employee's inventions may either be owned by employees even if they were created during work, providing to the employer the chance to acquire the invention either by express assignment, by implication if the employee's task included to (eventually) create inventions, or through the "shop-right"-model, if the invention was created during work-time and under use of working equipment provided the employer (Bales 2013), basically having the effect that the inventing employee originally owns the invention, but has to grant the employer the right to acquire the invention, i.e. to apply for a patent in the employer's own name, but based on the employee's invention. In those countries which apply the shop-right-doctrine - among them Germany, expressed in in its Arbeitnehmererfindungsgesetz (ArbNErfG, act on employees' inventions) - this right includes the employee's duty to give notice to the employer about any eventual invention made (see e.g. sec. 5 ArbNErfG) and "offer" it to his employer, after which - after a respective reform of the German employees' invention law - the acceptance of the employer is assumed he does not refuse to make use of the invention on behalf of the company within four months (e.g. sec. 6, 7 ArbNErfG). Does he decide to make use of the invention, the employee is in return entitled to a respective monetary gratification (art. 9-12 ArbNErfG), whose calculation - due to the broad variety of inventions and their eventual economic significance - is a true challenge in practice; the expected profit arising from the invention, the tasks and the position of the employee in the company as well as the company's proper contribution to the invention have to be taken into account (Schwab 2014).

This regulation provides at least a general approach of how interests of inventor and a non-identical patent holder (here the employer) in the situation of "employee-driven innovation" can be balanced. It may be argued that this model cannot be applied directly on the situation of user-driven innovation, as there is an essential difference: While the inventing employee and his employer are bound by a joint employment contract, there is no contractual relationship between the user providing innovative improvements in a virtual community and the innovationexploiting company. The central element of the employees'-invention-regulation is the company's right to "shop" the (until then foreign) invention, which is directly based on the underlying work- or service contract with the 
employee. Also the duty to disclose any invention to the company derives directly from the contract employeeemployer and cannot be imposed on any classical user in user-driven-innovation situations.

But there is another element in employee's invention law which does not arise from contractual relationships, but serves exclusively that balance of interest also envisaged in user driven innovation: The gratification paid to the employee distributes a respective share of the profit made by the company expected on base of the new patent, and as diverge national regulations of these gratifications may be in practice: The duty to pay a respective gratification - including its calculation methods - can be respectively applied to the favor of users in user-driven innovation as well, rendering the company's approach sustainable. As the user does often not know which company may exploit his invention in future - and as there would not be any duty to inform anybody about eventual inventions for users anyway - the information duties would be reversed, i.e. the interested company would be obliged to disclose its intention to patent the invention to its respective author (as far as possible). If the author does not react within a period of time still to be determined, his consent would be assumed - leaving untouched his claim for gratification, if he only finds out about the patent later.

\section{Conclusions}

The way technical innovation is generated in companies has essentially changed in recent years, and the trend has just started: No internal research department of any company has the resources to compete with the "wisdom of the crowd" provided by millions of private product users every day - in real time, based in real experiences, and - so far - at no costs. User provide these services to company as the "Open Source Spirit" - which is based on an informal understanding of mutual benefit of all actors involved, leaving any claims for monetary compensation aside - is still alive in the internet community, and as many users do not realize that their improvements disclosed on the web have indeed an - eventually considerably high - market value at all.

The estimation of the benefits of user innovation communities for companies is manifold comprising sustainability aspects due to stronger user orientation in product development as well as significant cost aspects as Cooper and Kaplan and Specht at al. pointed out due to their analysis of all success dimensions and all phases of the life-cycle supply chain of a product. Consequently the large potentials in the usage of innovations from user communities have to be kept in mind when it comes to the evaluation of related tentative IPR payments to users.

While the exploitation of this knowledge is at present basically free for private companies and therefore is becoming more and more essential in the firms' scheme (partly even replacing classical R\&D-departments), the Open Source Spirit will sooner or later fade, as users will realize that there is not much of a mutual benefit left if their inventive contributions do not serve a public good, but the profit of private companies.

This does not mean that the trend to even more user-driven innovation should be stopped or even reverted - on the opposite, the abundant resource of user's experiences should even be explored further, and the communication between users and private companies should further be intensified. But there should be a legal framework for these considerable transfers of value, providing sustainability and a minimum of balance of interests of both users and companies. This framework is so far lacking in virtually most legal systems, as the dogmatically closest legal mechanism - employee's invention law - cannot be directly applied on user driven innovation due to the lack of any legal relationship between the innovating user and the exploiting company. Still, there is one element in employee's invention law, which is not based on a contract between both parties - the duty to pay a respective gratification to the inventor. This duty should be imposed respectively on companies exploiting user-driven innovation - at least as far they want exclusively exploit the innovation on base of a patent or a utility model.

\section{References}

Alexy, O.; Reitzig, M. 2013. Private-collective innovation, competition, and firm's counterintuitive appropriation strategies, Research Policy 42: 895-913.

Asheim, B.; Gertler, M. 2005. The geography of innovation, The Oxford handbook of innovation, 291-317. 
Bales, R. 2013. US Employment Law perspectives on the issue of who owns an employee's invention in Pittard, M.; Modotti, A.; Danns, Y (Eds.). Business innovation and the Law. Elgar, 191-2134.

Bartl, M. 2008. White Paper: Open Innovation! Available on the Internet: <http://hyve.de/cms/upload/f_1599_WhitePaper_OpenInnovation.pdf>. [Accessed 15 Jun 2014]

Boone, C.; Craighead, C.; Hanna, J. 2008. Postponement. An Evolving Supply Chain Concept, International Journal of Physical Distribution \& Logistics Management 37(8): 594-611.

Boschma, R.A.; Ter Wal, A.L.J. 2007. Knowledge networks and innovative performance in an industrial district: The case of a footwear district in the South of Italy, Industry and Innovation 14(2): 177-199.

Breschi, S.; Malerba, F.; Orsenigo, L. 2000. Technological regimes and Schumpeterian patterns of innovation, The Economic Journal 110 (463): 388-410.

Chesbrough, H. 2003. Open Innovation: The New Imperative for Creating and Profiting from Technology. Boston: Harvard Business School Press.

Chesbrough, H.; Brunswicker, S.; 2013. Managing Open Innovation in large Firms. Fraunhofer Gesellschaft, Stuttgart.

Cohen, B.; Winn, M. I. 2007. Market imperfections, opportunity, and sustainable entrepreneurship, Journal of Business Venturing 22(1): $29-49$.

Cooper, R.; Kaplan, R. 1999. Design of Cost Management Systems. 2nd ed. Upper Saddle River, NJ: Prentice Hall.

Figurska, I. 2014. Sustainable entrepreneurship: localization, acquiring and use of knowledge sources in competitive organization, Entrepreneurship and Sustainability Issues 1(4): 210-222. DOI: http://dx.doi.org/10.9770/jesi.2014.1.4(3)

Gächter, S.; von Krogh, G.; Haeflinger, S. 2010. Initiating private-collective innovation: The fragility of knowledge sharing, Research Policy 39: 893-906.

Gerlach, A. 2003. Sustainable entrepreneurship and innovation, in University of Leads, The 2003 Corporate Social Responsibility and Environmental Management Conference, 30 June - 1 July 2003, Leads: UK, 101-110.

Gertler, M.S.; Levitte, Y.M. 2005. Local nodes in global networks: The geography of knowledge flows in biotechnology innovation, Industry and Innovation 12(4): 487-507.

Gibbert, M.; Leibold, M.; Gilbert, P. 2002. Five styles of Customer Knowledge Management, and how smart companies use them to create value, European Management Journal 20(5): 459-469.

Gilsing, V.; Bekkers, R.; Bodas Freitas, I.; van der Steen, M. 2011. Differences in technology transfer between science-based and development-based industries: Transfer mechanisms and barriers, Technovation 31: 638-647.

Hall, B. 2014. Does patent help or hinder technology transfer? in Ahn, S. (Ed.). Intellectual property for economic development. Elgar, 1132.

Heizer, J.; Render, B. 2013. Operations Management. Pearson.

Henkel, J.; Schöberl, S.; Alexy, O. 2013. The emergence of openness: How and why firms adopt selective revealing in open innovation, Research Policy 43(5): 879-890.

Jaworski, B.; Kohli, A.K. 1993. Market orientation: Antecedents and consequences, Journal of Marketing 57: 53-70.

Klett, A.; Sonntag, M.; Wilske, S. 2008. Intellectual Property Law in Germany. Beck Munich.

Kristensson, P.; Gustafsson, A.; Archer, T. 2004. Harnessing the creative potential among users, Journal of Product Innovation Management 21: 4-14.

Lerner, J.; Tirole, J. 2002a. The simple economics of open source, The Journal of Industrial Economics 50(2): 197-234.

Lerner, J.; Tirole, J. 2002b. Some simple economics of open source, Journal of Law, Economics, and Organization 21(1): 20-56.

Malerba, F. 2005. Sectoral systems of innovation: a framework for linking innovation to the knowledge base, structure and dynamics of sectors, Economics of Innovation and New Technologies 14(1-2): 63-83. 
Marsili, O. 2001. The Anatomy and Evolution of Industries: Technical Change and Industrial Dynamics. Edward Elgar Publishing Ltd., Cheltenham.

Pahlow, L. 2008. Erfindungsschutz vor Patenterteilung [Invention patent protection]. Gewerblicher Rechtsschutz und Urheberrecht (GRUR), 97-103.

Pavitt, K. 1984. Sectoral patterns of technical change: towards a taxonomy and a theory, Research Policy 13: 343-373.

Porter, M. 2000. Location, Competition and Economic Development: Local Networks in a Global Economy, Economic Development Quarterly 14(1): 15-34.

Prandelli, E.; Sawhney, M.; Verona, G. 2008. Collaboration with customers to innovate: Conceiving and marketing products in the network age. Cheltenham.

Prause, G.; Thurner, T. 2014. User Communities - Drivers for Open Innovation, Foresight - Russia 8(1): 24-32.

Schwab, B. 2014. Der Arbeitnehmer als Erfinder [The employee as an inventor], NZA-RR, 281-287.

Simchi-Levi, P.; Kaminsky, D.; Simchi-Levi, E. 2010. Designing and Managing the Supply Chain. $3^{\text {rd }}$ edition, McGraw-Hill.

Smith, K. 2000. Innovation as a systemic phenomenon: rethinking the role of policy, Enterprise and Innovation Management Studies 1(1): 73-102.

Specht, G.; Beckmann, G.; Almelingmeyer, J. 2002. F\&E Management: Kompetenz im Innovationsmanagement [R \& D Management: Competence in Innovation Management]. 2nd edition, Stuttgart.

Tödtling, F.; Lehner, P.; Trippl, M. 2006. Innovation in knowledge intensive industries: The nature and geography of knowledge links, European Planning Studies 14 (8): 1035-1058.

Tönnies, J. 2013. Erfindungen - ein Kollektivgut oder die Gedanken sind frei [Inventions - a thoughts are free], Gewerblicher Rechtsschutz und Urheberrecht (GRUR), 796-798.

Tvaronavičienè, M. 2014. If industrial sector development is sustainable: Lithuania compared to the EU, Entrepreneurship and Sustainability Issues 1(3):134-142. DOI: http://dx.doi.org/10.9770/jesi.2014.1.3(2)

von Hippel, E.; de Jong, J.P.J.; Flowers, S. 2012. Comparing business and household sector innovation in consumer products: Findings from a representative study in the United Kingdom, Management Science 58(9): 1669-1681.

von Hippel, E. ; Ogawa, S. ; de Jong, J.P.J. 2011. The age of the consumer-innovator, MIT Sloan Management Review 53(1): 27-35.

von Hippel, E. 1988. Lead user analysis for the development of new industrial products, Management Science 34(5): 569-582.

von Hippel, E.; von Krogh, G. 2003. Open Source Software and the 'Private-Collective' Innovation Model: Issues for Organization Science, Organization Science 14: 209-223.

Young, W.; Tilley, F. 2006. Can business move beyond efficiency? The shift toward efficiency and equity in the corporate sustainability debate, Business Strategy and the Environment 15(6): 402-415.

Zhao, F. 2005. Exploring the synergy between entrepreneurship and innovation, International Journal of Entrepreneurial Behaviour \& Research 11(1): 25-41.

Thomas HOFFMANN is DAAD-Lecturer in Law at the Faculty of Law at Tartu University, Estonia. Research interests: Comparative private law (law of obligations, consumer law), intellectual property, information technology law. He has served three years as a member of the committee drafting a new Estonian intellectual property code at the Estonian Ministry of Justice and teaches and researches at Tallinn Law School of Tallinn University of Technology as well. Being an attorney admitted to the German bar, he keeps touch to legal practice working for the law firm bnt Attorneys-at-Law in Tallinn. A list of his publications is available at <http://bit.ly/1fz4RkT>.

Gunnar PRAUSE is Professor for International Business in Tallinn School of Economics and Business Administration (TSEBA) of Tallinn University of Technology. Research interests: International Business, Entrepreneurship \& SME - Management, Logistics, Innovation. He is Board Member of the Centre for Business Research and Development at the Department of Business Administration of TSEBA, Board Member of the Institute of Cooperative Studies at Humboldt University Berlin, Board Member of Baltic China Science Park Network. He is author of more than 100 scientific articles.

This is an open access journal and all published articles are licensed under a Creative Commons Attribution 4.0 International License 